\begin{tabular}{l|l} 
Jurnal Eksplorasi Akuntansi \\
Vol 2, No 4, Seri D, November 2020, Hal 3671-3687
\end{tabular} \mid $\begin{aligned} & \text { ISSN : 2656-3649 (Online) } \\
& \text { http://jea.ppj.unp.ac.id/index.php/jea/issue/view/32 }\end{aligned}$

\title{
Analisis Representasi Gender Dalam Laporan Tahunan Perusahaan BUMN Sektor Jasa Di Indonesia Tahun 2016-2018
}

\author{
Novia Larasari ${ }^{1}$, Sany Dwita ${ }^{2}$ \\ ${ }^{1}$ Alumi Jurusan Akuntansi Fakultas Ekonomi Universitas Negeri Padang. \\ ${ }^{2}$ Jurusan Akuntansi Fakultas Ekonomi Universitas Negeri Padang. \\ *Korespondensi: novialarasari3@gmail.com
}

\begin{abstract}
This study aims to provide an analysis and understanding of gender representation in the annual report of BUMN service sector companies in Indonesia. The object of this research is PT Adhi Karya Tbk, PT Garuda Indonesia Tbk, PT Gas Negara Tbk, PT Pembangunan Perumahan Tbk, PT Telekomunikasi Indonesia Tbk. This study uses a qualitative descriptive approach with secondary data types obtained from the Annual Report of Service Sector BUMN Companies in Indonesia. Data collection was carried out by using documentation techniques by collecting human photos in the company's annual report. The analytical method used is content analysis. The research steps are: 1) identifying photos of people in the annual report, 2) grouping photos according to employees or non employees, only men, only women, or men and women together, 3) description of the number of photos according to group, 4) interpret the research results contained in the annual report. The results show that the description of gender in the annual report of the BUMN Service Sector Company does not support equality between men and women. Employee photos in the annual report are dominated by men compared to women. Through the analysis of gender photos described in the annual report, it was found that male gender dominated in terms of roles, places, clothes and body language. However, in the analysis of relative positions, men and women are shown standing or sitting the same.
\end{abstract}

Keywords : Annual Report; Gender Equality; Representation.

How to cite (APA $6^{\text {th }}$ style):

Larasari, Novia \& Dwita,Sany. (2020). Analisis Representasi Gender Dalam Laporan Tahunan Perusahaan BUMN Sektor Jasa di Indonesia Tahun 2016-2018. Jurnal Eksplorasi Akuntansi. 2(4), Seri D, 3671-3687.

\section{PENDAHULUAN}

Kesetaraan gender merupakan salah satu perwujudan keadilan dalam Hak Asasi Manusia. Kesetaraan gender adalah isu yang terus diperbincangkan. Para pemimpin bisnis mendesak pemerintah dan sektor swasta untuk memastikan perempuan dan laki-laki memiliki akses dan manfaat yang sama dari peluang ekonomi. Mereka mengatakan Indonesia berpotensi kehilangan US\$135 miliar dalam Produk Domestik Bruto tahunan jika gagal mengatasi kesetaraan gender dalam enam tahun ke depan (Hasan, 2019). 
Ketidaksetaraan gender merupakan suatu permasalahan utama yang dihadapi hampir di seluruh negara di dunia karena dianggap sangat bertentangan dengan hak fundamental yang dimiliki manusia yakni Hak Asasi Manusia. Hanya dengan menerapkan kebijakan dan UndangUndang yang kuat, makaakan mengubah situasi ini menjadi lebih baik. ILO menemukan bahwa kondisi ini hampir tidak berubah selama 27 tahun terakhir (Schlein, 2019).

Dalam profesi akuntansi, akuntan perempuan mungkin menjadi subyek bias negatif tempat kerja sebagai konsekuensi anggapan akuntan publik dalam profesi stereotype laki-laki. Bias negatif adalah bias yang merugikan salah satu pihak, sehingga menimbulkan ketidakadilan. Partisipasi wanita dalam pengambilan keputusan masih sangat lemah di dalam dunia politik, sosial maupun ekonomi (Sujatmoko, 2011).

Kyriacou (2016) menyatakan perbedaan dalam persepsi sosial terkait dengan masalah gender dapat mempengaruhi dinamika profesi. Pengaruh ini dapat dilihat pada komposisi perempuan yang cenderung lebih sedikit atau minoritas dalam profesi. Tidak dapat dipungkiri bahwa perempuan masih merasa sulit untuk memasuki profesi karena kekuasaan, upah dan perwakilan di tingkat politik dan administrasi tertinggi (Broadbent dan Kirkham, 2008). Ketidaksetaraan gender pada akhirnya dapat dipahami sebagai hasil dari norma kelembagaan dan perilaku internal.

Penelitian tentang representasi gender dalam laporan tahunan telah dilakukan oleh beberapa peneliti di beberapa negara seperti Belanda dan Thailand yang penduduk mayoritasnya nonmuslim. Penelitian di beberapa negara Belanda dilakukan oleh Benschop dan Meihuzen (2002) meneliti tentang representasi gender dalam laporan tahunan 30 perusahaan di Belanda dengan melakukan analisis terhadap teks, statistik, dan gambar. Benschop dan Meihuzen menyimpulkan bahwa konotasi maskulin gagal merepresentasikan keberagaman gender dalam laporan tahunan. Kuasirikun (2011) dengan melakukan analisis terhadap foto yang terdapat dalam laporan tahunan perusahaan di Thailand. Penelitian tersebut bertujuan untuk memahami bagaimana gender tergambarkan melalui foto dalam annual report perusahaan. Penelitian ini menemukan bahwa gender cenderung digambarkan sesuai dengan norma-norma yang ada dan bukan mempromosikan perubahan persepsi gender dalam masyarakat Thailand.

Gender bukanlah topik baru di bidang akuntansi. Peneliti sebelumnya telah melakukan beberapa studi gender untuk menemukan pengaruhnya di bidang akuntansi dan audit. Di bidang audit, peneliti memfokuskan penelitian tentang efek gender pada kualitas audit (Sari, 2014; Agustianto, 2013; Salsabila, 2011; Wulan dan Yuniarto, 2015). Penelitian sebelumnya telah banyak berfokus pada penelitian menggunakan pendekatan kuantitatif yang meneliti pengaruh gender dalam berbagai keputusan akuntansi yang dihasilkan (Dzulasri, 2018; Heinz et al, 2013; Ballantine \& Mccourt, 2011). Sedangkan penelitian sebelumnya yang berfokus dengan menggunakan pendekatan kualitatif dilakukan oleh Kuasirikun (2011), Husna (2017), Pauli (2016), Myzed (2017), Kamla (2012), dan Kryiacou (2016).

Kuasirikun (2011) melakukan penelitian terhadap foto-foto yang terdapat dalam laporan tahunan (annual report) perusahaan di Thailand. Dengan tujuan untuk memahami bagaimana gender dapat tergambarkan melalui foto dalam laporan tahunan perusahaan. Pauli (2016) melakukan penelitian tentang penggambaran gender dalam laporan tahunan perusahaan real estate di Swedia. Pauli telah memutuskan untuk menyelidiki perusahaan real estate karena perusahaan real estate umumnya didominasi oleh laki-laki. Penelitian ini dilakukan dengan menganalisis foto-foto dalam laporan tahunan perusahaan real estate. Sedangkan Husna (2017) dan Myzed (2017) melakukan penelitian menganalisis gambar dan foto yang terkandung dalam laporan tahunan bank syariah di Indonesia. Tujuan dari penelitian ini adalah untuk menganalisis 
penggambaran gender dalam laporan tahunan bank syariah di Indonesia. Peneliti memusatkan analisis pada laporan tahunan 3 kegiatan perbankan syariah selama periode 3 tahun.

Penelitian yang dilakukan oleh Kamla (2012) bertujuan untuk menyelidiki bagaimana globalisasi berdampak pada pengalaman akuntan perempuan di Suriah. Kamla (2012) melakukan penelitian tentang gender pada perempuan Suriah yang bekerja di bidang akuntansi dan keuangan dengan melakukan wawancara yang mendalam dengan para akuntan Suriah tersebut. Sedangkan Kyriacou (2016) melakukan penelitian pada Institusi Akuntansi Profesional di Yunani (SOEL). Kyriacou (2016) melakukan analisis gender melalui gambar atau foto pada website resmi Institusi Profesional Akuntan Yunani (SOEL) dengan menggunakan pendekatan Critical Discourse Analysis (CDA).

Gender di bidang akuntansi merupakan topik yang penting untuk diteliti. Akuntansi bukan hanya sekedar ilmu terapan atau ilmu pasti, tetapi akuntansi juga merupakan ilmu sosial. Akuntansi sebagai ilmu sosial diharapkan mampu untuk menyelesaikan permasalahanpermasalahan sosial, salah satunya adalah isu tentang ketidaksetaraan gender. Selain itu, gender berkaitan langsung dengan keberlangsungan profesi, jika terdapat ketidaksetaraan gender dalam suatu profesi, maka profesi tersebut tidak akan berjalan dengan baik. Permasalahan gender bukan hanya merupakan isu nasional, namun juga isu yang dibahas di kalangan internasional. Jadi, sebagai profesi akuntansi juga memiliki tanggung jawab sosial untuk menyelesaikan permasalahan tersebut, karena profesi akuntansi merupakan profesi yang global. Penelitian tentang gender di bidang akuntansi ini diharapkan mampu memberikan solusi atau menyelesaikan permasalahan-permasalahan terkait dengan isu ketidaksetaraan gender tersebut.

Annual report perusahaan menjadi sebuah alat komunikasi yang sangat penting bagi para stakeholder perusahaan (Kuasirikun, 2011). Dengan adanya perusahaan yang melakukan go public, maka informasi dapat dengan mudah diakses oleh para stakeholder berupa annual report perusahaan yang tidak hanya berisi identitas perusahaan saja, akan tetapi juga berisi laporan kinerja keuangan dan prospek perusahaan di masa yang akan datang (Woodward dalam Kuasirikun, 2011).

Penelitian akuntansi foto atau gambar sering diabaikan dan peranannya dianggap tidak sepenting angka atau teks. Penelitian akuntansi terdahulu telah banyak berfokus pada teks dan angka, namun untuk penelitian dengan foto masih terbilang sangat terbatas. Peneliti memilih untuk meneliti dengan menggunakan foto karena penelitian ini sangat relevan dengan era digital saat ini, dimana setiap perusahaan atau lembaga mengkomunikasikan informasi tentang detail perusahaan dan kegiatannya kepada publik secara digital dengan menggunakan foto sebagai media untuk merepresentasikan aktivitas dalam periode tertentu (Davison, 2010).

Secara umum jenis kelamin laki-laki berkaitan dengan jenis gender maskulin, sedangkan jenis kelamin perempuan berhubungan dengan jenis kelamin feminim. Dalam kehidupan sosial, feminitas dan maskulinitas tidak dapat dipisahkan dari laki-laki dan perempuan, karena feminitas dan maskulinitas melekat pada karakter perempuan dan laki-laki. Pendapat tentang gender seringkali mempengaruhi seseorang tentang bagaimana seharusnya laki-laki dan perempuan bertindak (Eagly \& Karau, 2002).

Badan Usaha Milik Negara (BUMN) merupakan salah satu badan yang dikelola oleh negara dalam upaya meningkatkan kesejahteraan masyarakat. Mayoritas saham BUMN dimiliki oleh pemerintah. BUMN adalah unit usaha yang sebagian besar atau seluruh modalnya berasal dari kekayaan negara yang terpisah dan menghasilkan suatu produk atau jasa yang dapat memberikan manfaat sebesar-besarnya bagi kesejahteraan rakyat. BUMN juga menjadi salah satu sumber pendapatan keuangan negara yang nilainya cukup tinggi (Wahyuni, 2009). 
Pemerintah telah menetapkan peraturan terkait dengan kesetaraan gender untuk perusahaan-perusahaan yang ada di Indonesia, tidak terkecuali untukBUMN. Peraturan tersebut ditetapkan dalam Undang-Undang No.7 Tahun 1984 tentang Penghapusan Segala Bentuk Diskriminasi terhadap Perempuan. Menurut Puspitosari dan Elok (2014), Undang-Undang ini memberikan pedoman bagi BUMN agar dalam proses perekrutan hingga penempatan tenaga kerja bertindak adil terhadap pekerja laki-laki dan perempuan dengan senantiasa memperhatikan kesetaraan dan keadilan gender.

Pedomanpenempatan tenaga kerja berwawasan gender ini kemudian disosialisasikan Pusat dan Daerah, dan kepada sebagian perusahaan, dan juga asosiasi yang tergabung dalam pengerahan jasa tenaga kerja. Sosialisasi dilakukan melalui pendidikan dan pelatihan, yang bertujuan memberikan pedoman bagi para pengambil keputusan di instansi pemerintah, BUMN, dan swastaagar dalam proses perekrutan hingga penempatan tenaga kerja bertindak adil terhadap pekerja laki-laki dan perempuan dengan senantiasa memperhatikan kesetaraan dan keadilan gender (Puspitosari dan Elok, 2014).

Penelitian ini bertujuan untuk melihat apakah perusahaan BUMN sektor jasa memiliki misi dan tanggung jawab sosial untuk mengurangi masalah ketidaksetaraan gender diperusahaanperusahaan BUMN sektor jasa, dengan cara mengamati foto-foto yang diterbitkan oleh perusahaan dalam laporan tahunan. Peran ini menunjukkan apakah BUMNmempublikasikan foto atau gambar laki-laki dan perempuan dalam laporan tahunan secara seimbang baik dari segi komposisi maupun peran. Sebaliknya, jika perusahaan BUMN sektor jasa lebih cenderung mempublikasikan foto atau gambar yang lebih didominasi oleh laki-laki, ini mengindikasikan bahwa perusahaan BUMN sektor jasa belum mempunyai misi umtuk mengurangi masalah ketidaksetaraan gender.

Peneliti tertarik untuk meneliti perusahaan BUMN sektor jasa yang terdaftar di Bursa Efek Indonesia (BEI) karena kesetaraan gender perusahaan BUMN sektor jasa dapat mendorong peningkatan produktivitas dan pertumbuhan bisnis secara signifikan. Oleh karena itu, berbagai inisiatif telah dilaksanakan untuk mendorong perusahaan menciptakan lingkungan kerja yang nyaman dan mendukung perubahan untuk mencapai kesetaraan gender di dunia kerja. (Setiawan, 2019). Perankesetaraan gender di dunia kerja masih menjadi tantangan di seluruh dunia, termasuk Indonesia. Padahal, kesetaraan gender yang diakui dapat memiliki dampak positif yang luas.

Oleh karena itu, berbagai inisiatif telah diambil untuk mendorong perusahaan untuk menciptakan lingkungan kerja yang nyaman bagi karyawan dalam berbagai peran, serta untuk mendukung perubahan untuk mencapai kesetaraan gender di dunia kerja. Persoalan kesetaraan gender tidak hanya terjadi di negara berkembang seperti Indonesia, namun menjadi topik yang menarik di seluruh dunia. Penelitian ini masih tergolong terbatas. Penelitian ini berfokus pada penelitian penggambaran representasi gender. Objek penelitian yang digunakan dalam penelitian ini adalah perusahaan BUMN sektor jasa yang terdaftar di Bursa Efek Indonesia (BEI) selama periode 2016-2018.

\section{REVIEW LITERATUR}

\section{Teori Stratifikasi Gender}

Teori stratifikasi gender adalah teori yang menjelaskan bahwa perempuan tidak memiliki peluang yang sama dengan laki-laki, tergantung pada gender. Teori stratifikasi gender dapat diterapkan pada berbagai situasi yang lebih luas (Brinton, 1998; Keister dan Southgate, 2012) dan mencakup kondisi perbandingan historis (Wermuth dan Monges, 2002; Scott, 1986). Stratifikasi gender ini membatasi akses perempuan dalam hal mencapai kekuasaan, prestise, dan 
properti berbasis gender (Treas dan Tai, 2016; Collins et al, 1993). Stratifikasi gender ini juga dapat didefinisikan sebagai ketidaksetaraan gender.

Dalam sudut pandang sosiologi, teori stratifikasi gender menjelaskan gagasan tentang munculnya ketidaksetaraan gender yang bertujuan untuk menciptakan suatu sistem, sosial, dimana sebagian penduduk akan bertanggung jawab atas beberapa bagian pekerjaan dan bagian lainnya bertanggung jawab untuk beberapa bagian dari pekerjaan (Brinton, 1998; Keister dan Soughte, 2012). Oleh karena itu, ketimpangan gender ini tampaknya menciptakan perbedaan sehubungan dengan tingkat tanggung jawab. Masalah utama adalah kecenderungan suatu kelompok dalam kelompok sosial untuk menjadi dominan, yang dapat memberikan tekanan pada kelompok lain (Treas dan Tai, 2016).

Teori stratifikasi gender menekankan pada penciptaan lapisan dalam masyarakat dan cara seseorang akan lebih kuat dari yang lain. Oleh karena itu, dari sudut pandang gender laki-laki adalah lapisan yang paling penting dan perempuan sebagai kelompok akan selalu mengambil posisi belakang dalam sejarah dan di panggung publik atau kekuasaan. Kesimpulan yang mendasari pernyataan diatas adalah bahwa laki-laki lebih superior dibandingkan dengan perempuan (Treas dan Tai, 2016; Kaister danSouthgate, 2012). Akibatnya, jika beberapa upaya dilakukan untuk meningkatkan jumlah perempuan yang memasuki dunia perusahaan, upaya ini akan menemukan masalah dalam harapan (misalnya gambar laki-laki yang dicetak) dan dalam kebanyakan kasus mereka akan mengalami kesulitan bekerja di berbagai karir (Treas dan Tai, 2016; Collins et al., 1993; Brinton, 1998).

\section{Teori Komunikasi}

Komunikasi adalah hubungan kontrak antar individu maupun kelompok. Tindakan suatu komunikasi harus bersifat emansipatif dan partisipatif sehingga dapat mencapai tujuan utama yaitu solidaritas dan keadilan. Emansipatif berarti menghilangkan elemen-elemen represif dalam suatu komunikasi dan partisipatif berarti adanya peran aktif dari semua subjek dalam suatu komunikasi. Menurut Habermas (1984) dalam Kuasirikun (2011), hasil pengembangan masyarakat dapat dilihat dari dua tingkat yang independen tetapi saling berhubungan, yaitu tingkat ekonomi dan tingkat komunikasi antara manusia. Habermas (1984), menekankan bahwa ekonomi bukan satu-satunya kekuatan pendorong dibalik perubahan sosial, tetapi bahwa ada juga faktor interaksi di antara anggota masyarakat, seperti adanya proses sosial, budaya dan rasional.

Keterkaitan teori Habermas (1989) dalam penelitian ini berfokus pada ranah publik dan penekannya pada komunikasi untuk menjelaskan demokrasi. Ranah publik menjadi tempat dimana masalah kepentingan publik dibahas secara demokratis dengan keputusan yang diambil secara rasional untuk pindah ke masyarakat yang lebih demokratis atau lebih baik untuk semua orang (Habermas, 1970).

Dalam konteks Habermas, penelitian ini berpendapat bahwa gambar yang terkandung dalam laporan tahunan memiliki nilai karena merupakan bagian dari klaim validitas perusahaan ketika perusahaan mencari pengertian bersama dengan berbagai stakeholder. Disini dikatakan bahwa untuk memenuhi syarat sebagai alat komunikasi yang paling efektif, akuntansi sebagai alat komunikasi harus mengirimkan informasi tentang intersubjektif untuk kepentingan semua anggota stakeholder untuk memastikan bahwa lifeworld dari masyarakat (yang berusaha untuk mewakili) muncul dengan cara yang lebih rasional dan seimbang (Habermas(1984) dalam Kuasirikun, 2011). Oleh karena itu, penelitian ini mencoba untuk menganalisis gambar dan annual report perusahaan dan mencoba memaknai gambar tersebut terkait dengan proses komunikasi dan rasionalisasi lifeworld dalam kehidupan akuntansi di Indonesia. 
Komunikasi adalah suatu proses penyampaian informasi baik itu pesan, ide maupun gagasan dari satu pihak kepada pihak lain.Laporan tahunan merupakan media yang digunakan perusahaan untuk menyampaikan pesan atau informasi kepada penguna laporan tahunan terkait dengan keadaan perusahaan. Kesetaraan gender di perusahaan dapat dilihat melalui gambar atau foto terkait dengan gender yang ada di dalam laporan tahunan perusahaan. Gambar atau foto tersebut dapat digunakan sebagai alat atau media untuk mengkomunikasikan kepada para pembaca laporan tahunan perusahaan tentang bagaimana keadaan kesetaraan gender yang ada diperusahaan. Jadi, hubungan teori komunikasi dengan gender adalah dengan menggunakan gambar atau foto terkait gender di dalam laporan tahunan perusahaan dapat memberikan informasi atau mengkomunikasikan kepada para pembaca laporan tahunan perusahaan tentang bagaimana kondisi kesetaran gender di perusahaan tersebut.

\section{Laporan Tahunan}

Laporan tahunan (annual report) adalah produk tertulis yang bertujuan untuk memberikan investor informasi spesifik tentang data keuangan dan deskripsi kegiatan operasi perusahaan. Laporan tahunan sebagai informasi tentang kesehatan perusahaan dan sebagai bentuk tanggung jawab terhadap investor dan penanam modal. Tujuan dari annual report menurut FASB 2010 adalah untuk menyediakan:

a. Informasi yang berguna dalam proses pengambilan keputusan investasi.

b. Informasi yang berguna dalam pengambilan keputusan kredit.

c. Informasi untuk mengevaluasi arus kas masa depan.

d. Informasi tentang sumber daya perusahaan, klaim untuk kompensasi terhadap sumber daya dan perubahan yang terjadi pada sumber daya.

Peraturan Badan Pengawasan Pasar Modal dan Lembaga Keuangan (Bapepam-LK) No.X.K.6 atau sekarang dikenal dengan Otoritasi Jasa Keuangan (OJK) mengharuskan perusahaan menerbitkan laporan tahunan yang tidak hanya memuat tentang informasi keuangan tapi juga memuat non keuangan. Dalam Undang-Undang No.40 tentang perseroan dijelaskan bahwa laporan tahunan harus memuat sekurang-kurangnya:

a. Laporan keuangan terdiri dari neraca pada akhir tahun keuangan sehubungan dengan tahun sebelumnya, laporan laba rugi untuk tahun tersebut, laporan arus kas dan laporan perubahan modal dan catatan atas laporan keuangan.

b. Laporan mengenai kegiatan perusahaan.

c. Laporan pelaksanaan tanggung jawab social dan lingkungan.

d. Rincian masalah yang muncul selama tahun itu yang memengaruhi aktivitas komersial perusahaan.

e. Laporan fungsi pengawasan yang dilakukan oleh dewan komisaris selama tahun fiskal terakhir.

f. Nama-nama administrator dan komisaris.

Pada awal perkembangan pelaporan keuangan, tidak banyak laporan keuangan perusahaan yang menggunakan gambar foto dineraca. Namun seiring berjalannya waktu, banyak perusahaan percaya bahwa gambar foto merupakan bagian penting dari laporan keuangan.

Menurut Kuasirikun (2011), Perkembangan penggunaan gambar dalam informasi keuangan awalnya hanya memberikan informasi tentang perusahaan, dengan kata lain ruang lingkup makna dari gambar tersebut hanya terbatas pada kegiatan perusahaan saja seperti perusahaan yang terlibat dalam kepemilikan menggunakan foto-foto sebuah bangunan. Namun seiring berkembangnya kebutuhan informasi dari para stakeholder perusahaan, gambar dalam laporan keuangan memiliki makna yang luas lingkupnya seperti contoh perusahaan yang didedikasikan untuk kepemilikan, perusahaan menyertakan foto seseorang yang sedang melihat 
bangunan yang belum selesai dari belakang jendela dengan senyum.Dari gambar ini dapat memiliki makna yang luas seperti visi perusahaan yang jelas di masa depan, senyum yang menggambarkan keramahan layanan perusahaan, senyum yang juga berarti budaya yang menguntungkan perusahaan untuk semua orang, pandangan penuh keyakinan yang berarti ambisius dan lain sebagainya seperti yang terdapat dalam Kuasirikun (2011).

Melalui foto, perusahaan dapat mengirimkan informasi tentang masalah gender dalam perusahaan. Masalah gender dalam perusahaan dapat berupa dominasi laki-laki di dalam perusahaan, jenis kelamin dari kepemimpinan perusahaan dan sebagainya. Oleh karena itu, pesan yang dikirimkan melalui foto-foto dalam laporan tahunan adalah salah satu strategi komunikasi perusahaan. Pemahaman tentang strategi komunikasi tidak dapat dipisahkan dari teori komunikasi yang dibentuk melalui proses sosial yang dicetuskan oleh Habermas (1984).

\section{Gender di Indonesia}

Gender dan jenis kelamin merupakan hal yang berbeda. Menurut Mansour (2011:8), jenis kelamin merupakan pensifatan atau pembagian dua jenis kelamin manusia yang ditentukan secara biologis yang melekat pada jenis kelamin tertentu. Elly (2011:872) menjelaskan bahwa jenis kelamin mengarah kepada pembagian fisiologi atau anatomis manusia secara biologis.

Kata gender dalam bahasa Indonesia merupakan kata serapan dari bahasa Inggris.Mansour (2013) menjelaskan bahwa tidak ada perbedaan antara kata gender dan jeniskelamin dalam kamus. Agar dapat memahami makna gender, terlebih dahulu harus paham perbedaan konsep gender dan jenis kelamin. Makna konsep gender yang merupakan sifat yang melekat pada lakilaki dan perempuan yang dikonstruksikan secara sosial maupun kultural. Seperti contoh, bahwa perempuan dikenal lemah lembut, cantik, emosional, atau keibuan. Berbeda dengan laki-laki yang dianggap kuat, rasional, perkasa, jantan. Ciri sifat itu sendiri yaitu sifat yang bisa dipertukaran. Dalam artian ada laki-laki yang lemah lembut, emosional, keibuan dan sebaliknya ada perempuan yang kuat, rasional, perkasa. Perubahan sifat-sifat tersebut bisa terjadi dari waktu ke waktu dan dari tempat ke tempat lainnya.

Menurut Mansour (2013)pembahasan tentang gender akan sangat erat kaitannya dengan konsep ketidaksetaraan gender. Perbedaan gender jugadianggap sebagai konsep yang menimbulkan ketidaksetaraan gender. Konsep perbedaan gender membahas perbedaan antara laki-laki dan perempuan. Sedangkan konsep ketidaksetaraan gender mengacu pada ketidakseimbangan/diskriminasi posisi perempuan terhadap posisi laki-laki dalam struktur kehidupan masyarakat saat ini. Ketidaksetaraan gender adalah suatu sistem dan struktur di mana laki-laki dan perempuan menjadi korban dari sistem tersebut. Ada beberapa manifestasi ketidaksetaraan gender menurut Mansour (2013), yaitu:

1. Marginalisasi Perempuan

Proses marginalisasi terhadap perempuan menghasilkan pemiskinan terhadap perempuan. Marginalisasi perempuan sudah terjadi sejak di rumah tangga dalam bentuk diskriminasi terhadap anggota keluarga laki-laki dan perempuan. Marginalisasi ini juga diperkuat oleh adat dan interpretasi beberapa agama.

2. Subordinasi Perempuan

Subordinasi perempuan terjadi karena lahirnya anggapan bahwa perempuan memiliki sifat irasional dan emosional, sehingga perempuan tidak bisa menjadi pemimpin, menghasilkan sikap yang menempatkan perempuan pada posisi yang tidak lebih penting daripada lakilaki.Ssebagai contoh dalam proses pengambilan keputusan keluarga, itu harus didasarkan pada persetujuan laki-laki. 


\section{Stereotip terhadap Perempuan}

Stereotip adalah label yang tertanam dalam kelompok tertentu. Ada banyak ketidakadilan untuk beberapa jenis kelamin, biasanya perempuan yang berasal dari pelabelan (stereotip) yang dilekatkan pada perempuan. Misalnya, diasumsikan bahwa tugas utama perempuan adalah melayani suami mereka.

4. Beban Kerja

Terdapat banyak perempuan yang melakukan pekerjaan rumah tangga dan menganggap diri mereka lebih rendah dari pekerjaan yang dilakukan oleh laki-laki. Apalagi jika perempuan itu bekerja di area publik, beban kerja perempuan akan berlipat ganda (double burden).

Elly (2011) menjelaskan bahwa masih banyak kendala budaya dan struktural yang membuat perempuan masih berjuang dengan kesulitan, terutama dalam partisipasi, pengambilan keputusan dan kekuasaan. Pada kenyataannya, ini disebabkan oleh lingkungan dan struktur budaya yang tidak mendukung terciptanya partisipasi penuh dari perempuan di dunia politik dan pengambilan keputusan.

Hal di atas juga terjadi dalam kehidupan akuntansi, seperti dalam penelitian Lindawati (2010) yang menyatakan bahwa perempuan di Indonesia sulit untuk menjadi akuntan profesional karena budaya yang diadopsi di Indonesia, yaitu budaya Jawa yang menuntut perempuan selalu di rumah dan tidak boleh melakukan perjalanan jauh serta perempuan memiliki tanggung jawab besar dalam menjalani rumah tangganya.

Seorang perempuan masih merupakan pihak minoritas dan digambarkan sebagai orang yang mendapat posisi pekerjaan sebagai bawahan pada pelaporan keuangan. Pengungkapan masalah dalam laporan tahunan perusahaan diperoleh melalui foto-foto yang terkandung di dalamnya (Kuasirikun, 2011). Dengan demikian, penelitian ini juga bermaksud mengidentifikasi bagaimana sebuah perusahaan melalui foto pada laporan tahunannya dalam mengungkapkan perbedaan gender.

\section{B. Penelitian Terdahulu}

Kuasirikun (2011) melakukan penelitian terhadap foto yang terdapat dalam laporan tahunan (annual report) perusahaan-perusahaan di Thailand. Penelitian tersebut bertujuan untuk memahami bagaimana gender dapat tergambarkan melalui foto dalam laporan tahunan perusahaan.Kamla (2012) melakukan penelitian tentang gender pada perempuan Suriah yang bekerja di bidang akuntansi dan keuangan dengan melakukan wawancara yang mendalam dengan para akuntan Suriah tersebut. Penelitian tersebut bertujuan untuk menyelidiki bagaimana globalisasi berdampak pada pengalaman akuntan perempuan di Suriah. Kyriacou (2016) melakukan analisis gender melalui gambar atau foto pada website resmi Institusi Profesional Akuntan Yunani (SOEL) dengan menggunakan pendekatan Critical Discourse Analysis (CDA). Kyriacou (2016) menemukan bahwa perempuan lebih sedikit direpresentasikan pada website SOEL dari pada laki-laki. Hal ini tidak sesuai dengan realitas SOEL yang mendukung kesetaraan gender sebagai agenda utama, namun Kyriacou (2016) beragumen bahwa adanya peningkatan penggambaran perempuan pada website menjadi sinyal positif bagi partisipasi perempuan dalam profesi akuntan di Yunani.

Penelitian dilakukan di perusahaan real estate karena perusahaan real estate merupakan perusahaan yang umumnya didominasi oleh laki-laki di Swedia. Pauli mengungkap bahwa lakilaki yang sedang sendirian digambarkan sebagai seorang karyawan di perusahaan sedangkan saat laki-laki dan perempuan ditampilkan bersamaan dalam stereotip posisinya masing-masing. Perempuan yang sendirian digambarkan mengisi posisi token. Pauli melakukan penelitian dengan 
menganalisis foto yang ada laporan tahunan perusahaan real estate dengan beberapa tahapan metode.

Untuk penelitian penggambaran gender di Indonesia masih tergolong sangat terbatas. Husna (2017) dan Myzad (2017) melakukan penelitian dengan menganalisis gambar dan foto yang terdapat pada laporan tahunan pada bank syariah di Indonesia. Penelitian yang mengalisis gender pada foto atau gambar melalui website resmi Institusi Profesional Akuntan tergolong penelitian yang baru.

\section{Kerangka Konseptual}

Berdasarkan landasan teori yang diuraikan di atas, maka kerangka konseptual yang digunakan pada penelitian ini adalah sebagai berikut:

\section{Gender Stratification di} Indonesia

a. Marginalisasi Perempuan

b. Subordinasi Perempuan

c. Stereotip perempuan

d. Differensial beban kerja
Pesan yang tersampaikan melalui Foto/ Komunikasi

a. Laki-laki secara dominan menempati jabatan yang lebih tinggi daripada perempuan.

b. Laki-laki lebih dominan menjadi pembicara/ pemateri dalam sebuah kegiatan daripada perempuan.

c. Laki-laki secara lebih dominan direpresentasikan sebagai pimpinan daripada perempuan.

d. Laki-laki secara dominan berpartisipasi dalam sebuah forum/ kegiatan daripada perempuan.

\section{Gambar 1. Kerangka Konseptual}

\section{METODE PENELITIAN}

Penelitian ini menggunakan pendekatan deskriptif kualitatif. Pendekatan kualitatif lebih tepat digunakan dalam penelitian ini, karena penelitian ini bertujuan untuk memahami dan menganalisis bagaimana penggambaran gender dalam laporan tahunan perusahaan BUMN di sektor jasa.

Populasi dalam penelitian ini adalah perusahaan BUMN pada sektor jasa yang terdaftar di Bursa Efek Indonesia (BEI) tahun 2016 sampai dengan 2018 yang berjumlah sebanyak 5 perusahaan yaitu PT Adhi Karya Tbk, PT Garuda Indonesia Tbk, PT Gas Negara Tbk, PT Pembangunan Perumahan Tbk, PT Telekomunikasi Indonesia Tbk. Untuk penelitian ini dilakukan pada perusahaan BUMN yang terdaftar di Bursa Efek Indonesi (BEI).

Metode yang digunakan untuk mengumpulkan data dalam penelitian ini adalah metode dokumentasi dengan mengumpulkan yang tertulis dan berhubungan dengan masalah penelitian yaitu representasi gender. 


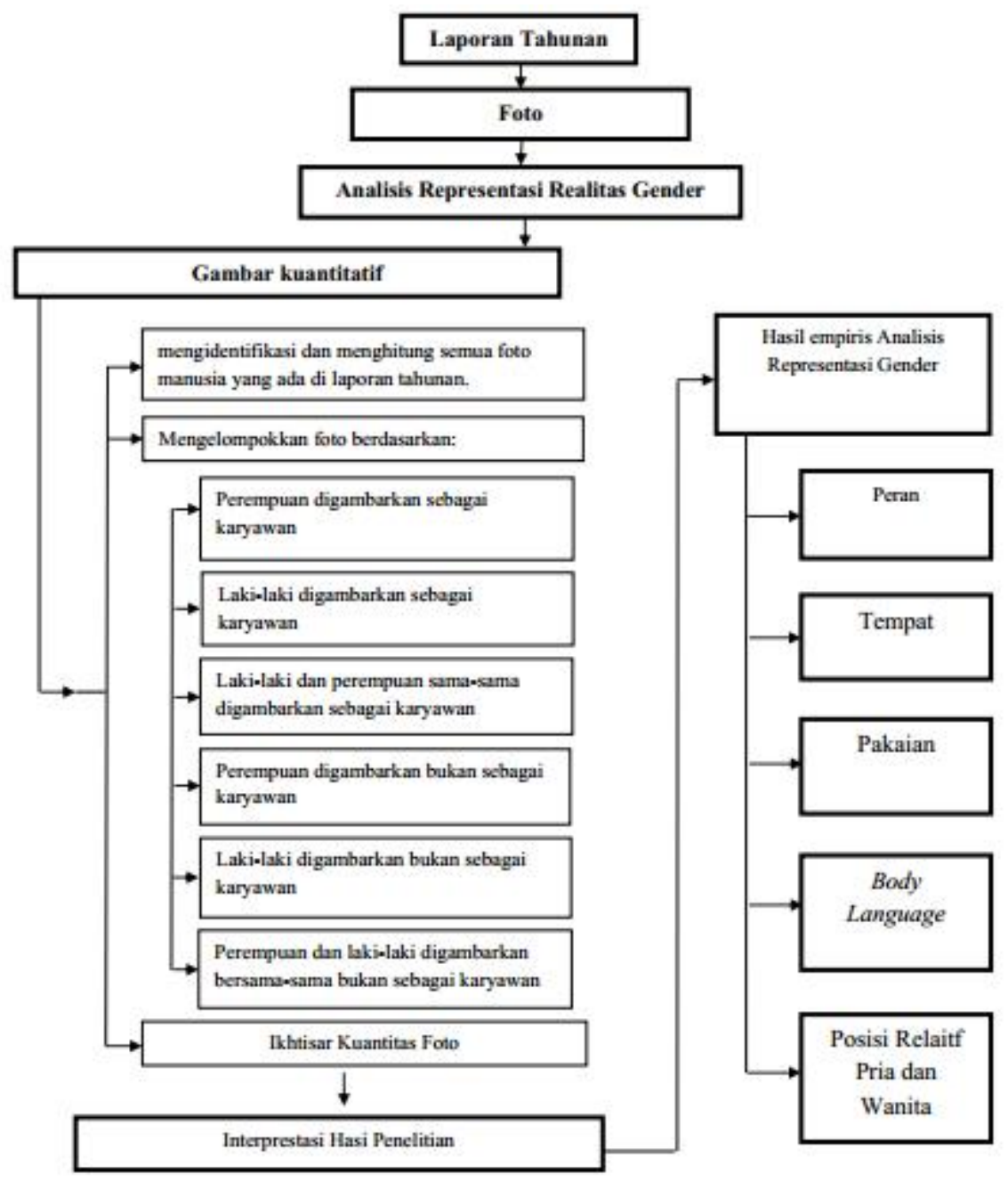

Gambar 2. Prosedur Penelitian dan Analisis Data (sumber: Husna, 2017)

\section{HASIL DAN PEMBAHASAN \\ Gambaran Kuantitatif}

Analisis kuantitatif dari foto-foto dalam laporan tahunan perusahaan BUMN Sektor Jasa menunjukkan bahwa sebagian besar dari foto yang ditampilkan dalam laporan tahunan memuat foto karyawan dan sebagian besar merupakan foto laki-laki saja. Dalam laporan tahunan perusahaan BUMN Sektor Jasaditampilkan foto laki-laki saja sebagai karyawan sebanyak $61 \%$ (2016), 77\% (2017) dan 75\% (2018) dari foto yang ada dalam laporan tahunan. Foto perempuan saja sebagai karyawan ditampilkan setiap tahunnya yaitu sebesar 17\% (2016), 15\% (2017) dan 17\% (2018). Laporan tahunan perusahaan BUMN Sektor Jasamenampilkan nonkaryawan sangat sedikit dalam laporan tahunannya yaitu sebanyak 22\% (2016), 8\% (2017) dan 8\% (2018).

Berdasarkan penjelasan diatas dapat disimpulkan bahwa secara kuantitatif, foto karyawan lebih sering ditampilkan dalam laporan tahunan Perusahaan BUMN Sektor Jasa. Sedangkan foto nonkaryawan ditampilkan relatif sedikit. Foto yang ditampilkan dalam laporan tahunan Perusahaan BUMN Sektor Jasa lebih banyak menampilkan foto laki-laki, sedangkan perempuan lebih sedikit. Perbedaan yang sangat signifikan ini sejalan dengan stereotip yang berlaku di masyarakat Indonesia bahwa laki-laki memiliki kesempatan yang lebih baik dan lebih luas untuk 
mengambil suatu profesi dibandingkan perempuan. Hasil ini sesuai dengan penelitian Kuasirikun (2011) yang menemukan bahwa laki-laki digambarkan dengan persentase yang jauh lebih tinggi dari pada penggambaran perempuan.

\section{Interpretasi Hasil Penelitian}

\section{Peran}

Analisis kuantitatif awal untuk menunjukkan pola peran gender pada Perusahaan BUMN Sektor Jasa dimana laki-laki dan perempuan muncul untuk melakukan tugas yang berbeda. Dalam laporan tahunan Perusahaan BUMN Sektor Jasa posisi pimpinan dalam perusahaan didominasi oleh laki-laki. Laki-laki digambarkan sebagai pimpinan sebanyak 95\% (2016), 92\% (2017), dan 95\% (2018) sesuai dengan stereotipnya yang berkembang dimasyarakat Indonesia yaitu bahwa laki-laki memiliki kedudukan yang lebih tinggi daripada perempuan. Namun dalam posisi karyawan, perbedaaan antara laki-laki dan perempuan tidak terlalu signifikan. Laki-laki dan perempuan ditampilkan yaitu 72\% (2016), 77\% (2017) dan 42\% (2018) sedangkan perempuan setiap tahun 28\% (2016), 23\% (2017) dan 58\% (2018).

Tabel 4 menunjukkan diferensiasi yang jelas dalam peran laki-laki dan perempuan. Lakilaki relatif lebih sering digambarkan dalam laporan tahunan dalam posisi yang tinggi dalam perusahaan. Namun, peran perempuan dalam posisi yang berpengaruh dalam perusahaan mulai ditampilkan walaupun dengan persentase yang jauh lebih sedikit daripada laki-laki. Dapat dilihat disini bahwa perempuan diberi ruang untuk menempati posisi sebagai pengambil keputusan dalam perusahaan.

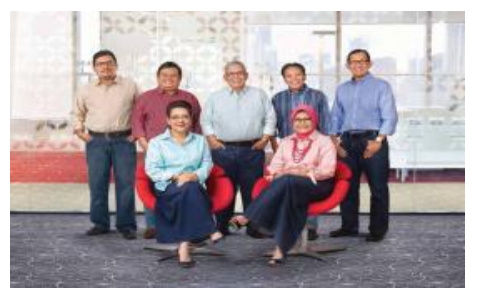

Gambar 1. TLKM 2016

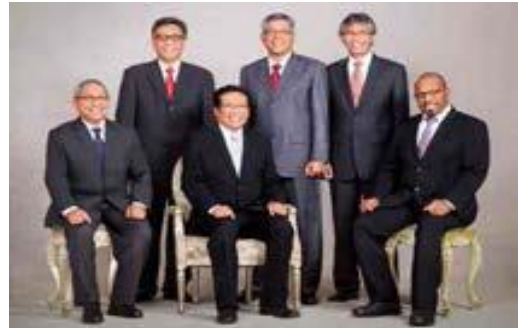

Gambar 2. ADHI 2016

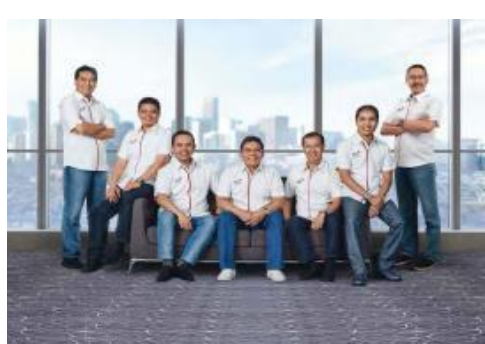

Gambar . TLKM 2016

Gambar 1 merupakan gambar jajaran dewan komisaris pada tiap-tiap perusahaan BUMN sektor jasayang ditampilkan dalam laporan tahunan. Dalam gambar ini dapat dilihat bahwa dalam posisi tinggi ini perempuan juga tampil sebagai salah seorang bagian dari dewan komisaris. Gambar ini menunjukkan bahwa di perusahaan BUMN sektor jasa,perempuan mempunyai kesempatan untuk menempati posisi yang lebih tinggi daripada laki-laki yaitu sebagai seorang pemimpin dalam perusahaan. Dapat kita lihatbahwa perempuan juga direpresentasikan dalam posisi tinggi. Perempuan perusahaan BUMN sektor jasa memiliki kesempatan yang sama dengan laki-laki untuk mengisi peran kepemimpinan di perusahaan.

Gambar 2 dan 3 menampilkan gambar jajaran dewan direksi dalam laporan tahunan. Dalam posisi tinggi ini dapat dilihat bahwa perempuan tidak menempati posisi sebagai salah satu 
bagian direksi. Gambar ini menunjukkan bahwa perempuan belum mempunyai kesempatan yang sama dengan laki-laki untuk menempati poisisi sebagai seorang pimpinan yang lebih tinggi dalam perusahaan. Sesuai dengan Stratifikasi gender yang berkembang di Indonesia.

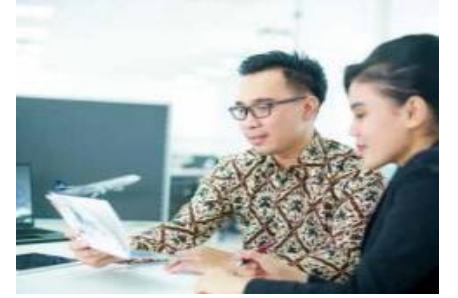

Gambar 4. GIIA 2016

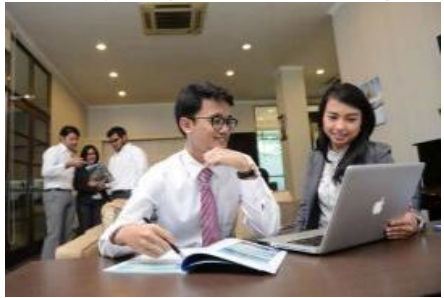

Gambar 5. PTPP 2016

Gambar 4 dan 5 menampilkan peran laki-laki dan perempuan sebagai karyawan. Terlihat bahwa pada laporan tahunan Perusahaan BUMN Sektor Jasa gambar yang menampilkan kedua jenis kelamin, laki-laki dan perempuan digambarkan kurang lebih sama dalam kedudukannya sebagai karyawan.

Berdasarkan uraian tentang peran gender dalam masing-masing perusahaan yang telah dijelaskan maka dapat diketahui bahwa penggambaran peran gender Perusahaan BUMN Sektor Jasa di Indonesia terdapat perbedaan antara penggambaran laki-laki dan perempuan dalam hal mengisi posisi tinggi dalam perusahaan. Laki-laki mendominasi setiap peran yang ditampilkan. Namun kesenjangan antara laki-laki dan perempuan sudah mulai berubah dengan terlihatnya peluang perempuan menempati posisi yang tinggi dalam perusahaan. Dalam menampilkan peran karyawan pun sudah mulai terlihat kesetaraan kedudukan antara laki-laki dan perempuan. Berbeda dengan peran perempuan yang ditampilkan dalam laporan tahunan perusahaan di Thailand yang diteliti oleh Kuasirikun (2011) yang menemukan bahwa perempuan sering ditampilkan menempati posisi yang sangat berbeda dengan laki-laki yaitu sebagai pekerja pabrik atau sebagai ibu rumah tangga yang digambarkan sebagai seorang konsumen.

\section{Tempat}

Gambaran kuantitatif dari lokasi gender yang ditunjukkan dalam laporan tahunan Perusahaan BUMN Sektor Jasa. Dari uraian di atas dapat dilihat bahwa lokasi representasi gender memiliki frekuensi yang hampir sama antara laki-laki dan perempuan, tidak ada perbedaan yang mencolok antara penggambaran lokasi perempuan dan laki-laki dalam laporan tahunan Perusahaan BUMN Sektor Jasa. Karyawan cenderung digambarkan dalam lingkungan profesional yaitu kantor dan klien dan lainnya dalam pengaturan non-profesional.

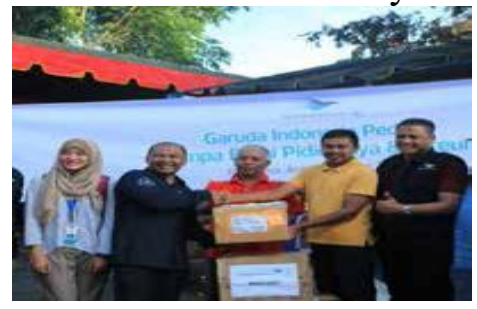

Gambar 6. GIIA 2016

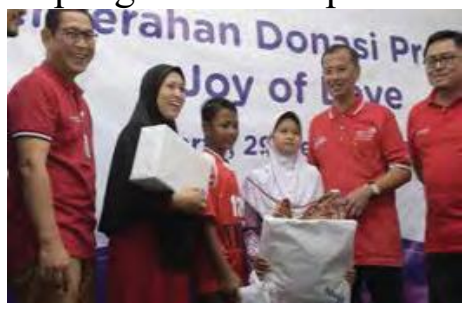

Gambar 7. TLKM 2016

Gambar 6 dan 7 menampilkan penggambaran perempuan di lokasi yang berada diluar organisasi atau kantor. Perempuan dan laki-laki digambarkan sebagai karyawan PT Garuda Indonesia (GIAA) Tbk yang sedang melakukan kunjungan bantuan ke lokasi. Berdasarkan uraian pada tabel dan penjelasan dalam foto-foto di masing-masing Perusahaan BUMN Sektor Jasa di 
atas, dapat disimpulkan bahwa posisi di mana gender digambarkan konsisten dengan cara peran gender ditampilkan. Peran yang ditampilkan sebagian besar menyangkut karyawan, sehingga foto-foto lokasi berada di kantor. Namun, foto pimpinan perusahaan tidak dapat ditentukan lokasinya karena foto tersebut ditampilkan sebagai profil pemimpin. Tidak ada perbedaan dalam posisi laki-laki dan perempuan dalam laporan tahunan perusahaan.

\section{Pakaian}

Pakaian yang dikenakan dalam foto yang ditampilkan dalam laporan tahunan Perusahaan BUMN Sektor Jasasesuai dengan peran yang ditampilkan. Sama seperti lokasi gender, pakaian yang digunakan pun konsisten dengan peran. Peran pimpinan dan karyawan ditampilkan dengan menggunakan pakaian formal. Laki-laki yang menggunakan pakaian formal ditampilkan sebanyak 69\% (2016), 80\% (2017) dan 79\% (2018). Sedangkan perempuan yang menggunakan pakaian formal sebanyak 21\% (2016), 16\% (2017) dan 17\% (2018). Foto yang menggunakan pakaian nonformal sangat sedikit dalam laporan tahunan. Laki-laki ditampilkan menggunakan pakaian nonformal sebanyak 5\% (2016), 4\% (2017) dan 0\% (2018). Perempuan memakai pakaian nonformal 4\% (2016), 0\% (2017) dan 3\% (2018). Hal ini konsisten dengan sedikitnya peran sebagai nonkaryawan yang ditampilkan pada Perusahaan BUMN Sektor Jasa.

Berdasarkan tabel dan deskripsi di atas, dapat disimpulkan bahwa representasi gender melalui pakaian di Perusahaan BUMN Sektor Jasa.di indonesia tidak menunjukkan perbedaan antara laki-laki dan perempuan. Perbedaan dalam representasi pakaian yang ditampilkan lebih dipengaruhi oleh perannya. Karena foto dalam laporan tahunan Perusahaan BUMN Indonesia lebih didominasi oleh foto karyawan dan pimpinan organisasi, maka pakaian yang sering ditampilkan merupakan pakaian Formal.

\section{Body Language}

a. Peran Pembicara

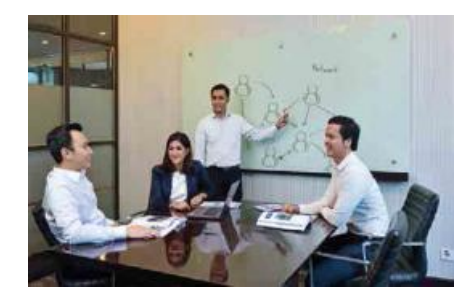

Gambar 8. PTPP 2017

Dapat dilihat Gambar 8 yang memperlihatkan karyawan laki-laki mengadakan rapat kerja. Dari gambar tersebut, dapat disimpulkan bahwa perempuan dan laki-laki tidak memiliki peluang dan peran yang sama untuk berbicara atau menjadi pembicara utama dalam suatu forum/kegiatan. Dalam menggambarkan situasi diskusi/pertemuan yang diadakan perempuan disajikan sebagai pelengkap diskusi, bukan sebagai pembicara aktif dalam diskusi. Dapat dilihat pada gambar 8 hanya ada satu perempuan. Ini kembali ke stereotip bahwa laki-laki diakui sebagai pemimpin dan perempuan memiliki posisi lebih rendah daripada laki-laki.

Jarang ditemukan seorang perempuan yang menggambarkan dirinya sebagai seorang pemimpin dalam suatu diskusi atau pertemuan. Kita bisa melihat bahwa tidak ada perempuan yang menjadi pembicara yang muncul dalam gambar dalam laporan tahunan Perusahaan BUMN, ini menjadi tanda negatif dalam penyajian laporan tahunan dalam kaitannya dengan kesetaraan gender laki-laki dan perempuan tidak memiliki kemampuan dan kesempatan yang sama untuk menjadi bagian penting dalam kegiatan ini. 

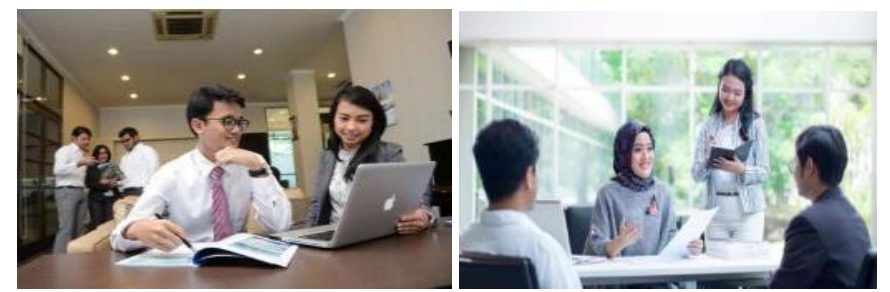

Gambar 9. PTPP 2016 Gambar 10. GIIA 2017

Dapat dilihat gambar 9 dan 10 memperlihatkan sesama karyawan yang sedang melakukan diskusi atau rapat kerja, dari ketiga gambar tersebut bisa kita lihat laki-laki maupun perempuan memiliki peluang dan peranan yang sama dalam menjadi pembicara dalam sebuah kegiatan diskusi/rapat. Hal ini menunjukkan perempuan sudah mulai memiliki peluang dan peranan yang sama untuk menjadi pembicara utama dalam sebuah diskusi/rapat.

Dari penjelasan diatas dapat ditarik makna bahwa laki-laki maupun perempuan sudah mulai memiliki peluang dan peranan yang sama untuk menjadi pembicara dalam sebuah forum/kegiatan. Hal ini merupakan sebuah kemajuan, dalam mengurangi stereotip yang berkembang yang menstratifikasikan bahwa perempuan merupakan peserta pasif dan cenderung tidak bisa melakukan apa yang bisa dilakukan oleh laki-laki, termasuk untuk menjadi pembicara dalam sebuah kegiatan. Adanya peranan perempuan melalui penggambaran ini, menjadi tanda positif dalam penyajian laporan tahunan dalam kaitannya dengan kesetaraan gender dimana perempuan sudah mulai memiliki kemampuan dan kesempatan yang sama dengan laki-laki untuk menjadi bagian penting dalam kegiatan ini. Sesuai dengan stratifikasi gender yang terjadi di Indonesia.

b. Laki-laki sebagai pembuat kesepakatan
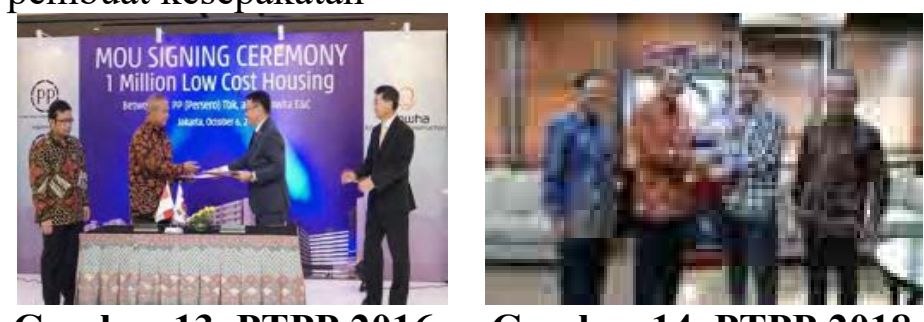

Gambar 13. PTPP 2016

Gambar 14. PTPP 2018

Gambar 13 dan 14 ini mewakilkan seluruh gambar dalam kegiatan perjanjian kerjasama atau membuat kesepakatan yang ditampilkan dalam laporan tahunan Perusahaan BUMN Sektor Jasa yang menampilkan laki-laki bersalaman dalam membuat kesepakatan dengan klien. Posisi ini memperkuat anggapan bahwa laki-laki identik lebih rasional dalam hal pengambilan keputusan daripada perempuan.

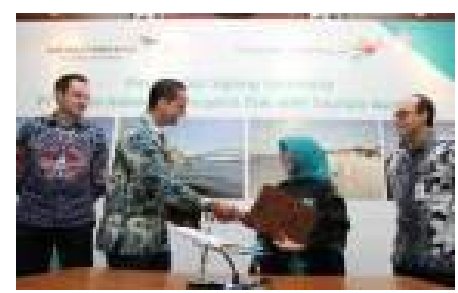

Gambar 15. GIIA 2017

Gambar 15 laki-laki ditampilkan bersalaman dengan perempuan yang juga sedang melakukan perjanjian kerjasama. Hal ini menunjukkan bahwa posisi rasional dalam pengambiln 
keputusan ini tidak hanya identik ditempati laki-laki, perempuan sudah mulai terlibat dalam pengambilan keputusan.

\section{Posisi relatif laki-laki dan perempuan}
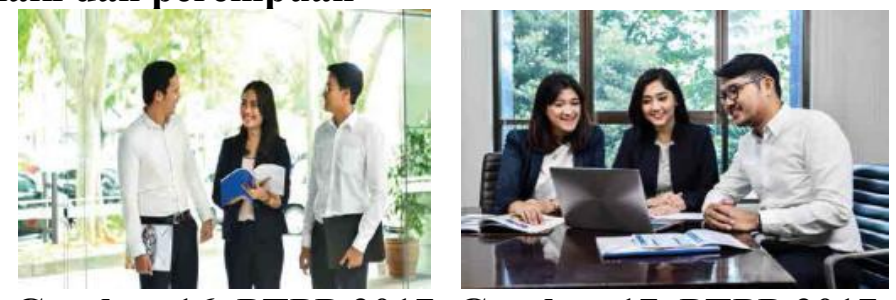

Gambar 16. PTPP 2017 Gambar 17. PTPP 2017

Gambar 16 dan 17, Menampilkan posisi relatif laki-laki dan perempuan adalah sama, hal ini dapat dilihat pada gambar 16 posisi relatif laki-laki dan perempuan adalah sama-sama berdiri (tinggi). Pada gambar 17 posisi relatif laki-laki dan perempuan adalah sama-sama duduk (rendah). Ini menunjukkan bahwa Perusahaan BUMN Sektor Jasa Indonesia melambangkan laki-laki dan perempuan memiliki posisi sosial yang setara. Dalam laporan tahunan laki-laki dan perempuandigambarkan sama-sama berdiri atau duduk. Ini merupakan suatu bentuk upaya untuk mencapai kesetaraan gender yang di ideal, dengan tidak membedakan posisi relatif laki-laki dan perempuan.

\section{SIMPULAN, KETERBATASAN DAN SARAN Simpulan}

Gambaran kuantitatif keseluruhan foto yang ada dalam laporan tahunan Perusahaan BUMN Sektor Jasa Indonesia menunjukkan bahwa foto yang ditampilkan lebih banyak menggambarkan karyawan yang didominasi oleh foto laki-laki. Sedangkan foto perempuan sangat sedikit yang ditampilkan dalam laporan tahunan. Gambaran kuantitatif menunjukkan bahwa penggambaran gender dalam laporan tahunan tidak mendorong kesetaraan antara laki-laki dan perempuan dalam pekerjaan. Untuk laporan tahunan Perusahaan BUMN Sektor Jasa perempuan memiliki peluang yang terbatas untuk menjadi pemimpin sedangkan lelaki memiliki peluang yang lebih tinggi untuk menjadi pemimpin. Hasil analisis gambaran kuantitatif keseluruhan foto menunjukkan bahwa semua laporan tahunan belum mendukung kesetaraan gender.

\section{A. Keterbatasan}

Penelitian ini masih tergolong penelitian baru yang mengkaji aspek kualitatif berupa foto dalam laporan tahunan Perusahaan BUMN Sektor Jasa Indonesia. Penelitian ini berupa retorika yang bertujuan mengubah pandangan pengguna laporan tahunan tentang pentingnya aspek foto dalam laporan tahunan. Hasil analis penelitian ini mengandung unsur subjektivitas yang cukup tinggi. Hal tersebut dikarenakan metode yang digunakan dalam menganalisis content visual atas elit bisnis yang disajikan dalam laporan tahunan perusahaan. Selain itu, belum ada standar yang mengatur bagaimana pengungkapan foto dalam laporan tahunan, akan menambah kesulitan dalam membuat interprestasi.

\section{B. Saran Untuk Penelitian Selanjutnya}

Berdasarkan hasil penelitian yang sudah diperoleh, maka peneliti menyarankan peneliti selanjutnya untuk meneliti laporan tahunan Perusahaan BUMN Sektor Jasa Indonesia lainnya 
atau perusahaan yang berbeda dari penilitian ini. Selain itu, diharapkan para peneliti selanjutnya akan dapat lebih memahami pentingnya penampilan foto dalam laporan tahunan karena setiap kode yang ditampilkan dalam foto memiliki arti tersendiri. dan peneliti selanjutnya diperlukan menggunakan aspek kualitatif lain dalam penelitiannya seperti linguistik atau semiotika yang terdapat dalam laporan tahunan, sehingga dapat memberikan hasil analisis dan pengetahuan yang lebih spesifik mengenai gender pada perusahaan/organisasi.

\section{DAFTAR PUSTAKA}

Agustianto, Angga. 2013. "Pengaruh Profesionalisme, Pengalaman Auditor, Gender danKualitas Audit terhadap Pertimbangan Tingkat Materialitas dalam Proses Pengauditan Laporan Keuangan". Skripsi. Universitas Islam Negeri Syarif Kasim Hidayatullah Jakarta.

Ballantine, J. dan Mccourt, P. 2011. The Impact of Ethical Orientation and Gender onFinal Year Undergraduate Auditing Students Ethical Judgement. Accounting Education: An International Journal. Vol.20 (2), Hlm 87-201.

Benschop, Y and Meihuizen, HE. 2002. "Keeping Up Gendered Appearance: Representations Of Gender In Annual Reports". Accounting, Organizations and Society. Vol.27 (7), H1m: 611636.

Brinton, Mary C. 1998. "The Social-Institutional Bases Of Gender Stratification: Japan as An Illustrative Case". American Journal of Sociology.Vol.94, Hlm: 300-334.

Broadbent, Jane and Kirkham, Linda. 2008. "Glass Ceilings, Glass Cliffs or New Worlds?: Revisiting Gender and Accounting". Accounting and Accountability Journal. Vol. 21, Hlm: 465-473.

Collins, Randal, Chafetz, Saltzman J, Blumberg, Rae L, Coltrane, Scott, and Turner, Jonathan H. 1993."Toward an Integrated theory of Gender Stratification". Sociological Perspectives. Vol.36, Hlm:185-216.

Davison J. 2010. "[In]visible [in]tangibles: Visual Portraits of The Business Elite". Accounting, Organizations, and Society. Vol. 35, Hlm: 165-183.

Dzulasri, Warisya. 2018. "Pengaruh Budaya dan Gender Terhadap Keputusan Akuntan". Skripsi. Fakultas Ekonomi. Universitas NegeriPadang : Padang.

Elly M. Setiadi dan Usman Kolip. 2011. "Pengantar Sosiologi,Pemahaman Fakta Dan GejalaPermasalahan Sosial". Teori,Aplikasi, dan Pemecahannya. Jakarta: Kencana.

Habermas J. 1970. "Towards a Theory of Communicative Competence". Inquiry. Vol. 13, Hlm: 360-75.

Habermas J. 1984. The Theory of Communicative Action: Reason and The Rationalisation of Society (translated by McCarthy T.). Boston: Beacon Press. Vol. 1.

Habermas J. 1989. The Structural Transformation of The Public Sphere: An Inquiry Into a Category of Bourgeois Society (Translated by Burger T. with The Assistance of Lawrence F). Cambridge: Polity Press.

Heinz, P, Patel, C, dan Hellman, A. 2013. "Some Theoretical And Methodological Suggestions For Studies Examining Accountants Professional Judgments And Earning Management". Advances in Accounting, incorporating Advances inv International Accounting.

Husna, Fajriatul. 2017. "Analisis Representasi Gender Dalam Laporan Tahunan Bank Syariah Indonesia 2013-2015". Skripsi. Fakultas Ekonomi. Universitas Neger Padang : Padang.

http://www.Kompasiana.com."Kesetaraan Gender Masih belum Sepenuhnya Tercapai". Accessed on date Oktober $14^{\text {th }}, 2019$. 
https://www.Obsessionnews.com. "Isu Kesetaraan Gender Jadi Ancaman Indonesia". Accessed on date Oktober $14^{\text {th }}, 2019$.

http://www.voaindonesia.com. "Kesetaraan Gender Masih Lebar dalam Dunia Kerja". Accessed on date Oktober $14^{\text {th }}, 2019$.

ILO. 2015. "Tren Ketenagakerjaan dan Sosial di Indonesia 2014-2015 : Memperkuat Daya Saing dan Produktivitas Melalui Pekerjaan Layak". Jakarta: Kantor Perburuhan Internasional.

Kamla, Rania. 2012. "Syrian Women Accountants' Attitudes And Experiences At Work In The Context Of Globalization". Accounting, Organizations and Society. Vol. 37, Hlm: 188-205.

Keister, Lisa A. and Southgate, Darby E. 2012.Inequality: A Contemporary Approach to Race, Class, and Gender". Cambridge: Cambridge University Press.

Keputusan Ketua Bapepam dan LK Nomor Kep-431 / BL / 2012. "Penyampaian Laporan Tahunan Emiten Atau Perusahaan Publik". Jakarta: Kemenkeu RI.

Kuasirikun, Nooch. 2011."The Portayal Of Gender In Annual Reports In Thailand". Critical Perspectives On Accounting. Vol. 22, Hlm: 53-78.

Kyriacou, Orthodoxia. 2016. "Accounting For Images Of 'Equality’ In Digital Space: Towards An Exploration Of The Greek Accounting Professional Institute". Critical Perspective On Accounting. Vol. 35, Hlm: 35-37.

Lindawati and Smark, Ciorstan. 2010. "Education Into Employment? Indonesian and Moving from Business Education Into Professional Partisipation". E-journal of Business Education \& Scholarship of Teaching. Vol. 4 (2), Hlm. 29-42.

Mansour, Fakih. 2013. "Analisis Gender dan Transformasi Sosial". Yogyakarta: Pustaka Pelajar.

Myzed, Innes Dahlia. 2017. "Analisis Realitas Gender Dalam Laporan Tahunan Perusahaan Di Indonesia (Studi Kasus Pada Beberapa Bank Syariah Tahun 2013-2015". Skripsi. Fakultas Ekonomi. Universitas Negeri Padang: Padang.

Pauli Staffanson, K. 2016. "Representations Of Gender Of Gender In Annual Report In The Real Estate Industry In Sweden". Property management, Vol. 34 (1), Hlm: 5-17.

Puspitosari, Hervina dan Elok Putri Maharani. 2014. "Pengarusutamaan Gender Di Bidang Ketenagakerjaan".

Salsabila, Ainia., Hepi Prayudiawan. 2011. "Pengaruh Akuntanbilitas, Pengetahuan Audit, Gender Terhadap Kualitas Hasil Kerja Auditor Internal". Jurnal Telaah \& Riset Akuntansi. Vol. 4, Hlm: 155-175.

Sari, Astrina S. 2014. "Pengaruh Akuntanbilitas, Pengetahuan Audit, Gender, Dan Integritas Terhadap Kualitas Hasil Kerja Audit Internal". Skripsi Thesis. Riau: Universitas Islam Negeri Sultan Syarif Kasim.

Scott, Joan Wallach. 1986. "Gender: A Useful Category for Historical Analysis". The American Historical Review. Vol. 5, Hlm: 53-75.

Sujatmoko. 2011. "Analisis Kinerja Auditor dari Perspektif Gender Pada Kantor Akuntan Publik Di Jakarta".Skripsi. Jakarta: Universitas Islam Negeri Syarif Hidayatullah.

Treas, Judtih and Tsuio Tai. 2016. "Gender Inequality in Housework Across 20 European Nations". Lessons From Gender Stratification Gender Theories. Sex Roles. Vol.74, Hlm: 495-511.

Undang-undang No. 40 tahun 2007 tentang Perseroan Terbatas.

Wermuth, Laurie, and Miriam Ma'at-Ka-Re Monges. 2002. "Gender Stratification. A Structural Model for Examining Case Examples of Women in Less-Developed Countries". Frontiers: A Journal of Women Studies. Vol.23, Hlm: 1-22..

Wulan, Felia N. dan Yuniarto, Arif F. 2015. "Pengaruh Gender, Tekanan Ketaatan, Pengetahuan, Keahlian dan Pengalaman Terhadap Kualitas Audit". Journal. Universitas Ahmad Dahlan. 